\title{
EFEKTIFITAS MEDIA BOOKLET UNTUK MENINGKATKAN KONDISI PSIKOLOGIS SUAMI SETELAH ISTRI BERSALIN
}

\author{
Misrawati ${ }^{1}$, Yulia Irvani Dewi ${ }^{2}$, Yufitriana Amir ${ }^{3}$ \\ 1,2,3 PSIK Universitas Riau \\ Program Studi Ilmu Keperawatan Universitas Riau Jalan Pattimura No 9 Gedung G Pekanbaru Riau \\ Kode Pos 28131 Indonesia \\ Telepon 081275344557 email misra_wati@yahoo.co.id
}

\begin{abstract}
Abstrak
Perubahan kondisi psikologis setelah bersalin bukan hanya terjadi pada ibu yang mengalami persalinan, namun suami pun mengalami perubahan psikologis. Perubahan psikologis pada suami ini mulai dari yang ringan dalam bentuk cemas bahkan menjadi lebih berat yang disebut paternal postnatal depression (PPND). Pendidikan kesehatan dengan menggunakan media booklet merupakan salah satu langkah yang dapat mengatasi masalah ini, namun sejauh ini keefektifannya belum diteliti. Penelitian ini bertujuan meningkatkan kondisi psikologis suami setelah istri bersalin. Desain penelitian adalah quasi eksperiment dengan rancangan penelitian nonequivalent kontrol group design. Penelitian dilakukan di wilayah kerja Puskesmas Harapan Raya dan Puskesmas Lima Puluh Pekanbaru. Sampel dipilih dengan menggunakan metode purposive sampling dengan memenuhi kriteria inklusi. Responden berjumlah sebanyak 34 orang yang dibagi menjadi 17 orang kelompok eksperimen dan 17 orang kelompok kontrol. Pada pertemuan pertama diberikan penilaian terhadap skoring kondisi psikologis menggunakan instrumen Edinburgh Postnatal Depression Scale (EPDS), kemudian Kelompok eksperimen diberikan pendidikan kesehatan menggunakan Booklet, sedangkan kelompok kontrol sesuai kebiasaannya. Pada hari ke delapan diberikan kembali penilaian kondisi psikologis. Dari hasil penelitian didapatkan bahwa terjadi penurunan nilai skoring EPDS pada kelompok ekperimen sedangkan pada kelompok kontrol terjadi peningkatan nilai skoring EPDS. Dari uji statistik menggunakan Uji $T$ Independent didapat ada perbedaan signifikan nilai EPDS sesudah perlakuan pada kedua kelompok dengan $\mathrm{P}$ value $(0,000)$. Dapat disimpulkan bahawa pendidikan kesehatan menggunakan media booklet efektif meningkatkan kondisi psikologis suami setelah istri bersalin. Perlu tindak lanjut dari tenaga kesehatan dalam melakukan pendidikan kesehatan bukan hanya pada ibu yang akan bersalin tetapi juga perlu diberikan kepada suami dalam mempersiapkan kondisi psikologisnya.
\end{abstract}

Kata kunci: bersalin, pendidikan kesehatan, booklet, psikologis, suami

\section{Abstract}

Alteration psychological conditions after delivery not only occur among mothers who experienced labor, but also to their husbands. The mild alteration could be as anxiety after having baby and the severe alteration known as paternal postnatal depression (PPND). Health education using booklets can be one of nursing 
Misrawati $^{1}$, Yulia Irvani Dewi ${ }^{2}$, Yufitriana Amir ${ }^{3}$,Efektifitas Media Booklet Untuk Meningkatkan Kondisi Psikologis Suami Setelah Istri Bersalin

intervention to solve it. However, the effect of this intervention has not been investigated yet. This study aims to improve the psychological condition of the husband after delivery. The study design was nonequivalent control group design. The research was conducted in Harapan Raya Public Health Center and Lima Puluh Public Health Center Pekanbaru. Purposive sampling method was applied. Thirty four respondents were participated; 17 respondents as experiment group and 17 respondents as control group. An assessment of the Edinburgh Postnatal Depression Scale (EPDS) instrument of the psychological condition score was performed in the first day assessment.The experimental group was given a health education using the booklet. The second evaluation was performed on the eighth day. The result shown that there were a decrease of EPDS scores in experiment group and increase of EPDS scores in the control group. The Independent T Test shown that there was significant difference of EPDS value after treatment in both groups with P value (0.000). In summing up booklet can be one of recommended media for health education to prevent husband physcology alteration. Furthermore, care giver should give education about paternal postnatal depression (PPND) during antenatal and postnatal care.

Keywords: maternity, health education, booklet, psychological, husband

\section{PENDAHULUAN}

Gangguan psikologis hampir $80 \%$ terjadi pada perempuan setelah bersalin. Gangguan psikologis yang dirasakan mulai dari yang ringan yaitu postpartum blues sampai berat yaitu postpartum depression dan postpartum psychosis (WHO, 2003; Collingwood, 2010). Gangguan psikologis ini bukan hanya dialami oleh perempuan yang telah bersalin, namun suami juga dapat mengalami gangguan psikologis setelah istri bersalin.

Menurut Friedman, Bowden dan Jones (2014) gangguan psikologis pada suami ini dapat disebabkan karena perubahan hubungan dengan istri setelah melahirkan, peningkatan tuntutan pekerjaan, harapan budaya, kebingungan peran menjadi ayah dan perasaan yang tidak nyaman. Ditambahkan oleh Kim, dan Swain (2007) bahwa perubahan gaya hidup ini mempengaruhi beberapa hormone pada suami yaitu peningkatan hormone estrogen dan penurunan hormone testosterone, cortisol, vasopressin dan prolactin yang dapat mempengaruhi kejadian depresi postpartum.

Suami yang baru memiliki bayi pertama kali, $10 \%$ beresiko mengalami depresi postpartum (Kim, James \& Swain, 2011). Sekitar 4-25\% suami yang mengalami depresi setelah istri melahirkan pada bulan pertama dan kedua (Kim, James\& Swain, 2007). 
Menurut Paulson dan Bazemore (2010), Pada tahun pertama kelahiran, depresi pada suami terjadi sekitar $1.5-25.5 \%$ dan $24-50 \%$ terjadi pada suami yang istrinya juga mengalami depresi postpartum (Kokkinaki, 2016). Berdasarkan penelitian Misrawati dan Jumaini (2016) di Pekanbaru Riau-Indonesia, dari 200 suami setelah istri melahirkan 43 orang (21.5\%) mengalami kesemasan dan 13 orang (6.5\%) mengalami depresi.

Meskipun dalam angka terlihat kecil namun memberikan dampak yang berarti bagi istri dan anak. Laki-laki biasanya menampilkan emosi yang negative seperti marah, cemas, menarik diri dari lingkungan social, pesimis, takut, bingung dan melakukan kekerasan (Biebel \& Alikhan, 2016). Akibat gangguan psikologis pada suami dapat juga menurunkan keharmonisan rumah tangga dan memperburuk kondisi psikologis istri. Tingkat kepuasan seksual yang rendah dan kurangnya kasih sayang kepada istri juga merupakan dampak yang dikeluhkan suami (Ramchandani, et al, 2011). Kekerasan pada pasangan dan perselingkuhan sering dilakukan para suami yang mengalami depresi (Ogradniczuk \& Oliffe, 2011).
Gangguan psikologis suami juga berpengaruh terhadap perkembangan dan perilaku anak (Paulson \& Bazemore, 2010). Depresi menyebabkan kesulitan membentuk kedekatan hubungan ayah dengan anak, anak mengalami psikopatologi, gangguan emosi, sulit berteman dan berinteraksi dengan orang lain, gangguan perkembangan komunikasi, persepsi, kemampuan motoric dan cenderung berperilaku anarkis (Thurgood, 2009).

Psikologi suami setelah istri melahirkan perlu mendapatkan perhatian. Salah satu upaya yang dapat dilakukan adalah dengan memberikan psikoedukasi (Maideen, et al, 2016).

Selama ini psikologis suami kurang menjadi perhatian tenaga kesehatan karena berasumsi istrilah yang lebih bertanggung jawab terhadap dirinya. Selain itu suami jarang mendampingi istri dalam pemeriksaan antenatal sehingga penyuluhan hanya diberikan kepada istri. Jikapun suami dan istri hadir, pendidikan kesehatan yang diberikan hanya difokuskan kepada perawatan fisik yang dilakukan pada ibu.

Pendidikan kesehatan dengan menggunakan booklet lebih praktis dalam 
Misrawati $^{1}$, Yulia Irvani Dewi ${ }^{2}$, Yufitriana Amir ${ }^{3}$,Efektifitas Media Booklet Untuk Meningkatkan Kondisi Psikologis Suami Setelah Istri Bersalin

merangkum materi edukasi karena terangkum dalam suatu buku kecil yang dapat dibawa kemana saja dan dapat dipelajari kembali apabila penjelasan yang pernah diberikan terlupakan. Penggunaan media booklet biasanya disertai dengan penjelsan singkat sehingga memberikan pengetahuan dan pemahaman yang lebih cepat dan jelas kepada individu karena ada interaksi langsung disertai diskusi (Basri, Zulkifli \& Abdullah, 2014). Berdasarkan Soep (2009), istri yang diberikan psikoedukasi menggunakan booklet setelah melahirkan, $71.8 \%$ tidak mengalami depresi dibandingkan yang tidak diberikan psikoedukasi. Psikoedukasi menggunakan booklet juga sangat efektif dilakukan pada ibu yang berusia remaja dengan kelahiran anak pertama (Girsang, Novalina \& Jaji, 2015). Namun sejauh ini belum pernah dilakukan psikoedukasi dengan media booklet pada suami.

Penelitian ini bertujuan mengetahui efektifitas psikoedukasi dengan media booklet dalam meningkatkan kondisi psikologis suami setelah istri melahirkan. Hasil penelitian ini dapat bermanfaat bagi tenaga keperawatan sebagai strategi dalam melakukan pendidikan kesehatan pada suami dengan istri yang akan melahirkan.

\section{METODE PENELITIAN}

Desain penelitian ini adalah quasi eksperiment dengan rancangan penelitian nonequivalent control group design.

Populasi dalam penelitian ini adalah seluruh suami yang istrinya melakukan persalinan di wilayah kerja Puskesmas Harapan Raya dan Puskesmas Lima Puluh Pekanbaru. Teknik pengambilan sampel dilakukan secara purposive sampling yaitu teknik pengambilan sampel yang dilakukan berdasarkan pertimbangan tertentu (Notoadmojo, 2012). Sampel memenuhi kriteri inklusi yaitu suami yang memiliki istri antara 1-5 minggu setelah bersalin, persalinan pervaginam tanpa komplikasi, Skor EPDS $>4$, suami dan istri tidak memiliki riwayat gangguan jiwa.

Penelitian sebelum dilakukan telah lolos kaji etik oleh komite etik penelitian Fakultas Kedokteran Universitas Riau dengan nomor 458/UN.19.5.1.1.8/UEPKK/2017. Semua responden menyetujui sebagai responden 
dengan menandaangani informed consent dan dijamin kerahasiaan identitas responden dengan membuat hanya kode responden tanpa mencantumkan nama pada instrument.

Jumlah responden sebanyak 34 orang yang telah memenuhi syarat jumlah sampel minimal dalam penelitian eksperimen ditambah dengan 10\% kemungkinan drop out (Ruslan, 2013; Sastroasmoro dan Ismael, 2010). Responden dibagi menjadi 2 kelompok yaitu 17 orang kelompok eksperimen dan 17 orang kelompok control.

Responden didapatkan dari data rekam medis yang ada di puskesmas Harapan Raya dan Lima Puluh Kota Pekanbau. Responden yang didapatkan pertama kali sampai 17 orang merupakan kelompok control, sedangkan responden ke-18 sampai 34 merupakan kelompok control.

Pertemuan dengan responden dilakukan dirumah responden. Pada pertemuan pertama diberikan penjelasan tentang penelitian meliputi tujuan, manfaat penelitian, dan kesediaan menjadi responden yang ditandatangan dalam bentuk informed consent. Selanjutnya dilakukan pendidikan kesehatan dengan booklet (kelompok eksperimen), sedangkan kelompok kontrol tanpa diberikan intervensi. Setiap hari responden diiingatkan untuk melakukan pembelajaran yang telah diberikan melalui layanan pesan singkat melalui handphone. Pada hari ke delapan dilakukan penilaian kembali terhadap kondisi psikologis suami.

Alat ukur yang digunakan dalam penilaian kondisi psikologis suami adalah Edinburgh Postnatal Depression Scale (EPDS). EPDS dipilih sebagai instrumen penelitian karna EPDS merupakan instrumen baku dan berdasarkan hasil penelitian sebelumnya dinyatakan bahwa instrumen tersebut telah teruji dan diakui validitas dan reliabilitasnya. Menurut Tsai (2013) EPDS memiliki nilai sensitivitas 0.94 dan spesifisitas 0.77. Keakuratan kuesioner EPDS 90\% menurut Abadian Sharif. Sedangkan menurut Cox et al. pada 87 sampel tahun 1987, kuesioner ini sensitif, spesifik, dan memberikan prediksi nilai positif $86 \%, 78 \%$, dan $73 \%$ berturut-turut.

\section{HASIL PENELITIAN}

Hasil penelitian dipaparkan berupa data 
Misrawati ${ }^{1}$, Yulia Irvani Dewi ${ }^{2}$, Yufitriana Amir ${ }^{3}$,Efektifitas Media Booklet Untuk Meningkatkan Kondisi Psikologis Suami Setelah Istri Bersalin

karakteristik repsonden dan uji bivariat kedua

kelompok. Data karakteristik kedua kelompok lebih jelas dipaparkan pada tabel 1.

Tabel 1

Distribusi karakteristik responden

\begin{tabular}{|c|c|c|}
\hline Karakteristik & $\begin{array}{c}\text { Booklet }(\mathrm{n}=17) \\
\mathrm{f}(\%)\end{array}$ & $\begin{array}{l}\text { Kontrol } \\
(\mathrm{n}=17) \\
\mathrm{f}(\%)\end{array}$ \\
\hline $\begin{array}{l}\text { Umur } \\
\begin{array}{l}\text { a. }>25 \\
\text { b. } \quad<24\end{array}\end{array}$ & $\begin{array}{c}17(100) \\
0\end{array}$ & $\begin{array}{c}16(94.1) \\
1(5.9)\end{array}$ \\
\hline $\begin{array}{l}\text { Suku } \\
\text { a. Melayu } \\
\text { b. Minang } \\
\text { c. Batak } \\
\text { d. Jawa } \\
\text { e. Lain-lain }\end{array}$ & $\begin{array}{l}6(35.3) \\
5(29.4) \\
3(17.6) \\
1(5.9) \\
2(11.8)\end{array}$ & $\begin{array}{c}9(52.9) \\
4(23.5) \\
0 \\
3(17.6) \\
1(5.9)\end{array}$ \\
\hline $\begin{array}{l}\text { Paritas istri } \\
\text { a. Primipara } \\
\text { b. Multipara }\end{array}$ & $\begin{array}{l}6(35.3) \\
11(64.7)\end{array}$ & $\begin{array}{c}6(35.3) \\
11(64.7)\end{array}$ \\
\hline $\begin{array}{ll}\text { Pendidikan } \\
\begin{array}{cc}\text { a. } & \text { S1/D3 } \\
\text { b. } & \text { SMA } \\
\text { c. } & \text { SMP } \\
\text { d. } & \text { SD }\end{array}\end{array}$ & $\begin{array}{l}6(35.5) \\
7(41.2) \\
2(11.8) \\
2(11.8)\end{array}$ & $\begin{array}{c}6(35.3) \\
7(41.2) \\
4(23.5) \\
0\end{array}$ \\
\hline $\begin{array}{l}\text { Pekerjaan } \\
\begin{array}{l}\text { a. Pengawai } \\
\text { Negeri } \\
\text { b. Pegawai } \\
\text { Swasta } \\
\text { c. Wiraswasta } \\
\text { d. Lain-lain }\end{array}\end{array}$ & $\begin{array}{c}5(29.4) \\
0 \\
10(58.8) \\
2(11.8)\end{array}$ & $\begin{array}{l}2(11.8) \\
2(11.8) \\
8(47.1) \\
5(29.4)\end{array}$ \\
\hline
\end{tabular}

Dari uji statistik, semua karakteristik respon pada kedua kelompok memiliki homogenitas yang sama. Mayoritas kelompok berumur lebih dari 25 tahun, bersuku Melayu, memiliki anak lebih dari satu, pendidikan SMA dan bekerja sebagai wiraswasta.

Kondisi psikologis suami sebelum dan sesudah perlakuan dipaparkan pada tabel 2 dan grafik 1.

Tabel 2

Kondisi Psikologis Suami Sebelum dan Sesudah Perlakuan pada Kelompok Booklet dan Kontrol.

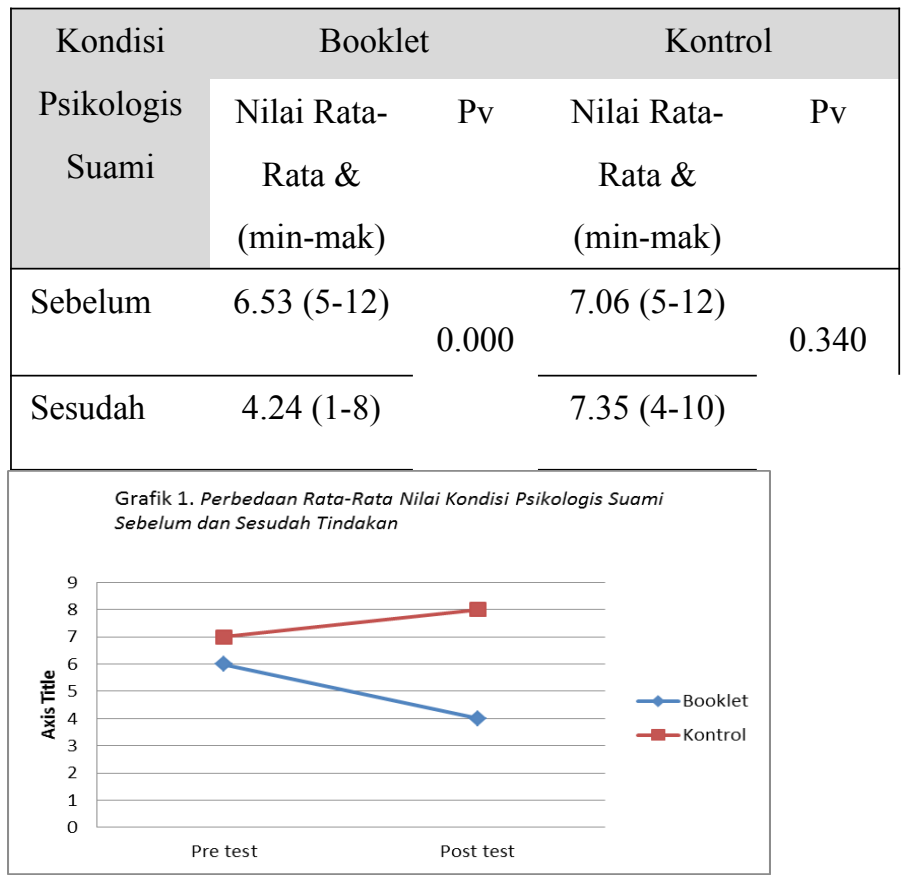

Dari grafik 2 terlihat penurunan skoring EPDS pada kelompok eksperimen sedangkan pada kelompok control justru terjadi peningkatan nilai EPDS. Dari uji statistik dengan menggunakan Wilcoxon test pada kedua kelompok, didapatkan kelompok eksperimen (booklet) Pvalue (0.000) < 0.05, 
artinya adanya perbedaan yang bermakna terhadap skoring EPDS suami sebelum dan sesudah perlakuan pada kelompok ekperimen dan tidak ada perbedaan skoring EPDS pada kelompok kontrol dengan Pvalue (0.340) .

Untuk menilai keefektifan psikoedukasi menggunakan media booklet dapat dilihat pada tabel 3 .

Tabel 3.

Kondisi Psikologis Suami Sesudah Perlakuan pada Kelompok Booklet dan Kontrol

\begin{tabular}{|l|c|c|}
\hline \multicolumn{1}{|c|}{ Kondisi Psikologis } & $\begin{array}{c}\text { Nilai Rata-Rata } \\
\text { (min-max) }\end{array}$ & P value \\
\hline $\begin{array}{l}\text { Sesudah pada } \\
\text { kelompok Booklet }\end{array}$ & $4.24(1-8)$ & 0.000 \\
$\begin{array}{l}\text { Sesudah pada } \\
\text { kelompok Kontrol }\end{array}$ & $7.35(4-10)$ & \\
\hline
\end{tabular}

Dari tabel 3 secara klinis terlihat perbedaan yang bermakna setelah perlakuan pada kelompok booklet yaitu penurunan skor EPDS sedangkan pada kelompok control skor masih tinggi. Secara uji statistik didapatkan ada perbedaan yang signifikan terhadap skoring psikologis suami setelah diberikan perlakuan pvalue $(0.000)<0.05$. Dapat diartikan bahawa pendidikan kesehatan menggunakan media booklet efektif meningkatkan kesehatan psikologis suami.

\section{PEMBAHASAN}

Berdasarkan karakteristik umur, respon mayoritas berimur $>25$ tahun yang berarti telah melewati syarat usia minimal untuk perkawinan bagi laki-laki di Indonesia (BKKBN, 2016). Usia ini dianggap telah siap dalam menghadapi kehidupan berumah tangga jika ditinjau dari segi social dan kesehatan. Pertambahan usia meningkatkan kemampuan berpikir secara kritis dan serius dalam melakukan sesuatu dan lebih rasional serta memikirkan dampak yang akan terjadi sesuai dengan yang telah dikerjakan (Notoadmojo, 2010).

Suku responden bervariasi karena Pekanbaru merupakan daerah pendatang. Penelitian menunjukkan bahwa suku suami yang menjadi responden bervariasi, namun sebagian besar suami bersuku Melayu. Indonesia terkenal dengan aneka macam suku bangsa yang tentunya menghasilkan ragam budaya yang sangat berpengaruh terhadap praktik hidup sehari-hari (Supartini, 2012). Perbedaan suku berpengaruh terhadap perilaku kesehatan, keyakinan, dan nilai-nilai yang dianut oleh seseorang (Winkelman, 2009). Suku juga memiliki harapan-harapan tertentu bagi seorang ayah (Friedman, Bowden, \& 
Misrawati $^{1}$, Yulia Irvani Dewi ${ }^{2}$, Yufitriana Amir ${ }^{3}$,Efektifitas Media Booklet Untuk Meningkatkan Kondisi Psikologis Suami Setelah Istri Bersalin

Jones, 2014).

Paritas istri responden pada penelitian ini adalah multipara. Pengalaman memiliki anak sebelumnya mempengaruhi sikap suami dalam menghadapi kelahiran bayi (Biebel \& Alikhan, 2016). Jumlah anak di dalam keluarga akan menentukan tingkat pengalaman keluarga dalam menghadapi kehadiran bayi. Suami yang baru memiliki anak $10 \%$ beresiko mengalami depresi postnatal (Paulson \& Bazemore, 2010). Sedangkan suami yang paritas istrinya multipara lebih mengkhawatirkan soal biaya hidup yang meningkat dan anak lainnya yang meminta perhatian lebih.

Pendidikan responden mayoritas Menengah Atas. Latar belakang pendidikan membentuk cara berpikir seseorang kemampuan memahami faktor yang berkaitan dengan penyakit dan menggunakan pengetahuan tersebut untuk menjaga kesehatan (Potter \& Perry, 2005). Semakin tinggi pendidikan seseorang semakin tinggi pemahamannya mengenai sesuatu (Notoadmojo, 2010).

Hasil penelitian menunjukkan bahwa mayoritas pekerjaan responden adalah wiraswasta. Hal ini juga didukung oleh data BPS Pekanbaru (2017) selain menjadi pegawai, $27.8 \%$ penduduk Pekanbaru memiliki lapangan usaha sendiri seperti berdagang, eceran dan rumah makan.

Penggunaan media booklet adalah kebutuhan menyediakan referensi (bahan bacaan) bagi individu yang mengalami keterbatasan untuk mengakses informasi (Simamora, 2009).

Setelah dilakukan intervensi psikoedukasi menggunakan media booklet didapatkan penurunan rata-rata skor EPDS sebesar 2.29 point dengan $p$ value $(0.000)<\alpha$ (0.05) maka dapat disimpulkan bahwa ada perbedaan signifikan penurunan rata-rata psikologis suami pada kelompok psikoedukasi booklet. Berdasarkan hasil penelitian Soep (2009) pendidikan kesehatan menggunakan booklet efektif menurukan kejadian ibu depresi postpartum sebanyak 65\% selama 30 menit. Media booklet juga efektif dalam menurunkan kejadian postpartum blues pada 20 ibu primipara yang berusia (Girsang, 2015).

Psikoedukasi merupakan pencegahan 
dan pengobatan tambahan yang efektif yang bisa dibawa kemana saja dan bisa meningkatkan pemahaman individu dan dipelajari kembali apabila ada kurang jelas dan keluarga mengenai gangguan psikologis terlupakan. Booklet mengharuskan individu (Bhattacharjee et al., 2011). Penggunaan media membaca sehingga daya serapnya efektif psikoedukasi sangat mempengaruhi perubahan sebesar 10\% (Muhson, 2010). Pengetahuan psikologis suami. Booklet merupakan media yang digunakan dalam memberikan edukasi dapat membantu memudahkan individu memahami, mengingat dan mempraktekkan apa yang sudah dipelajari (Kolid, 2012).

Berbeda dengan kelompok kontrol yang justru mengalami peningkatan skor EPDS, artinya terjadi peningkatan gangguan psikologis pada suami di group kontrol. Peningkatan gangguan psikologis suami setelah istri melahirkan dipengaruhi oleh banyak faktor yaitu kebingungan peran menjadi ayah, tuntutan pekerjaan yang meningkat, harapan budaya, perubahan hubungan dengan istri setelah melahirkan dan paling banyak adalah kebingungan peran menjadi ayah (Friedman, Bowden\& Jones, 2014; Biebel \& Alikhan, 2016).

Pada kelompok eksprimen dengan mendapatkan pendidikan kesehatan dengan media booklet lebih membuat praktis karena merangkum materi dalam sebuah buku kecil

\section{SIMPULAN}

Hasil penelitian dari 34 responden menunjukkan bahwa mayoritas karakteristik responden berusia $>25$, bersuku Melayu, paritas istri multipara, pendidikan SMA, dan 
Misrawati $^{1}$, Yulia Irvani Dewi ${ }^{2}$, Yufitriana Amir ${ }^{3}$,Efektifitas Media Booklet Untuk Meningkatkan Kondisi Psikologis Suami Setelah Istri Bersalin

pekerjaan wiraswasta. Psikoedukasi dengan menggunakan media booklet terhadap suami yang memiliki istri setelah melahirkan menunjukan penurunan skor gangguan psikologis sedangkan kelompok kontrol mengalami peningkatan gangguan psikologis dalam rentang seminggu setelah penilaian awal. Berdasarkan uji berpasangan sebelum (pretest) dan sesudah perlakuan (post test) dengan uji Wilcoxon, kelompok booklet dengan $p$ value $(0.000)<(0.05)$ sedangkan kelompok kontrol dengan $p$ value $(0.340)>$ (0.05). Hasil post test kedua kelompok dengan uji $T$ Independent diperoleh ada perbedaan yang signifikan skor psikologis suami pada kelompok booklet dan control dengan $p$ value $(0.000)>(0.05)$. Dapat disimpulkan psikoedukasi dengan menggunakan media booklet efektif meningkatkan kondisi psikologis suami setelah istri bersalin.

\section{SARAN}

\section{Bagi institusi/petugas kesehatan/pemerintah}

Penelitian ini dapat dijadikan evidence based practice dalam meningkatkan pelayanan dan memberikan psikoedukasi pada suami setelah istri melahirkan yang dapat dimulai sejak antenatal care. Adanya protap layanan kesehatan tentang pendidikan kesehatan bukan hanya pada istri tetapi melibatkan pasangannya.

\section{Bagi suami setelah istri melahirkan}

Suami dapat menerapkan materi dalam booklet untuk mengurangi gangguan psikologis yang dirasakan setelah istri melahirkan.

\section{Bagi peneliti selanjutnya}

Perlu dilakukan penelitian lebih lanjut dengan membandingkan media lain seperti pembuatan official account di WhatsApp/Line, web blog, video terhadap kondisi psikologis suami.

\section{DAFTAR PUSTAKA}

Biebel, K., \& Alikhan, S. (2016). Paternal postpartum depression. Journal of Parent \&Family Mental Health, 1, 1-4. Diperoleh tanggal 12 Desember 2016 dari http://escholarship.umassmed.edu/parenta ndfamily/vol1/iss $1 / 1$

Basri, A. H, Zulkifli, A., \& Abdullah, M. T. (2014). Efektifitas psikodukasi terhadap depresi postpartum di RSIA Siti Fatimah dan RSIA Pertiwi Makasar tahun 2014. Jurnal Unhas, 1-12. Diperoleh tanggal 23 Desember 2016 di 
http://pasca.unhas.ac.id

Bhattacharjee, D., Rai, A. K., Singh, N. K., Kumar, P., Munda, S. J., \& Das, B. (2011). Psychoeducation: a meansure to strengthen psychiatric treatment. Delhi Psychiatry Journal, 14(1), 33-39.

Diperoleh tanggal 3 Januari 2017 dari http://medind.nic.in

BKKBN. (2016). Materi bantu penyuluhan kependudukan, keluarga berencana, dan pembangunan keluarga. Jakarta:

Direktorat Kerja Sama Pendidikan Kependudukan BKKBN.

BPPS Kota Pekanbaru. (2017). Kota Pekanbaru dalam angka 2017. http://pekanbarukota. bps.go.id

Collingwood, J. (2010). The efficacy of postpartum depression screening. http://psychcentral.com/lb/2010.

Friedman, M. M., Bowden, V. R., \& Jones, E. G. (2014). Buku ajar keperawatan keluarga: riset, teori, \& praktik. Edisi 5. Jakarta: EGC.

Girsang, B. M., Novalina, M., \& Jaji. (2015). Pengaruh psikoedukasi terhadap tingkat postpartum blues ibu primipara berusia remaja. Jurnal Keperawatan Soedirman, 10(2), 114-120. Diperoleh tanggal 8 Desember $2016 \quad$ dari http://jks.fikes.unsoed.ac.id

Kim, P., James, E., \& Swain, J. E. (2007). Sad dads paternal postpartum depression. Psychiatry (Edgmont), 4(2), 35-47.

Diperoleh tanggal 29 Desember 2016 dari http://www.ncbi.nlm.nih.gov

Kim P., Feldman R., Mayes L. C., Eicher V., Thompson N., Leckman J. F. \& Swain J. E. (2011) Breastfeeding, brain activation to own infant cry, and maternal sensitivity. Journal of Child Psychology and
Psychiatry 52(8):907-15. Available at: http://www.ncbi.nlm.nih.gov | Google Scholar | PubMed

Kolid, A. (2012). Promosi kesehatan: dengan pendekatan teori prilaku, media dan aplikasainya. Jakarta: Rajagrafindu Persada.

Kokkinaki, T. (2016). Maternal and paternal postpartum depression: effect on early infant parent interctions. Journal of Pregnancy and Child Health, 3(1), 1-5. Diperoleh tanggal 13 Desember 2016 dari http://vi.scribd.com

Mahfoedz, I., \& Suryani, E. (2007). Pendidikan kesehatan promosi kesehatan.Cetakan ke-5. Yogyakarta: Fitramaya.

Maidden, S. F. K., Moh-Siddik, S., Rampal, L., Mukhtar, F., Ibrahim, N., Phang, C.K,., Tan, K.U \& Ahmad, R. (2016). A webbased psycoeducational intervention program for depression and anxiety in adult community in Selangor, Malaysia: Protocal of a ramdomized controlled trial. Jmir Reseach Protocols, 5(2), 112. Diperoleh tanggal 18 Desember 2016 dari http://ncbi.nlm.nih.gov.

Misrawati \& Jumaini. (2016). Analysis of paternal postnatal mental health in the land of Malay-Riau. The $1^{\text {st }}$ International Nursing Scholars Congress. Diperoleh tanggal 19 Januari 2017 dari http://conference.ui.ac.id.

Muhson, A. (2010). Pengembangan media pembelajaran berbasis teknologi informasi. Journal UNY. Diperolah tanggal $30 \quad$ Juni 2017 dari http://staff.uny.ac.id

Notoadmojo, S. (2012). Metodologi penelitian kesehatan. Jakarta: Rineka Cipta 
Misrawati ${ }^{1}$, Yulia Irvani Dewi ${ }^{2}$, Yufitriana Amir ${ }^{3}$,Efektifitas Media Booklet Untuk Meningkatkan Kondisi Psikologis Suami Setelah Istri Bersalin

Notoadmojo, S. (2010). Promosi kesehatan teori dan aplikasi. Jakarta: Rineka Cipta.

Ogrodniczuk, J. S., \& Oliffe, J. L. (2011). Men and depression. Canadian Family Physician, 57, 153-155. Diperoleh tanggal 28 Desember 2016 dari http://www.ncbi.nlm.nih.gov.

Paulson, J. F., \& Bazemore, S. D. (2010). Prenatal and postpartum depression in father and its association with maternal depression: a meta-analysis. Journal of the American Medical Association, 303, 19. Diperoleh tanggal 12 Desember 2016 dari http://www.ncbi.nlm.nih.gov.

Ramchandani, P. G., Psychogiou, L., Vlachos, H., Iles, J., Sethna, V., Netsi, E., \& Lodder, A. (2011). Paternal depression: an examination of its links with father, child, and family functioning in the postnatal period. Depression and Anxiety, 28, 471477. Diperoleh tanggal 18 Desember 2016 dari http:www.ncbi.nlm.nih.gov.

Potter \& Perry. (2005). Konsep perkembangan dan peran keluarga (Terjemahan). Jakarta: Salemba Medika.

Ruslan, R. (2013). Metode penelitian public relations dan komunikasi. Jakarta: Rajawali Pers.

Sastroasmoro, S., \& Ismael, S. (2010). Dasardasar metodologi penelitian klinis. Jakarta: CV Sagang Seto.

Simamora, R. H. (2009). Buku ajar pendidikan dalam keperawatan. Jakarta: EGC.

Soep. (2009). Pengaruh intervensi psikoedukasi dalam mengatasi depresi postpartum di RSU Dr. Piringadi Medan. Tesis. Diperoleh tanggal 2 Desember 2016 dari http://repository.usu.ac.id.
Supartini, Y. (2012). Buku ajar konsep keperawatan anak. Jakarta: EGC.

Thurgood, S., Daniel, B.S., \& Williamson, M.D.L. (2009). Postpartum depression (PPD). American Journal of linical edicine ${ }^{\circledR}$ - Spring 2009 - Volume Six, number Two.

Tsai, A. C., Et al. (2013). Reliability and validity of instruments for assessing perinatal depression in african settings: systematic review and meta-analysis. Plos one. 8(12), 1-9. Diperoleh tanggal 20 Januari 2017 dari http://www.plosones.org.

Winkelman, M. (2009). Culture and health: applaying medical anthropology. USA: Jossen.

World Health Organization. (2003). The World Health Report 2003. 